\title{
RISIKO PAPARAN ASAP ROKOK TERHADAP BBLR
}

\author{
Jumrina Muldianti ${ }^{1 *}$, Rani Mercy ${ }^{2}$, A Fahira Nur ${ }^{2}$ \\ ${ }^{I}$ Mahasiswa Kebidanan STIKES WIDYA NUSANTARA PALU \\ ${ }^{2}$ Bagian Kebidanan STIKES WIDYA NUSANTARA PALU \\ *Email:jumriamuldianti901@gmail.com
}

Masalah kesehatan adalah suatu masalah yang sangat kompleks yang saling berkaitan dengan masalah-masalah lain di luar kesehatan sendiri. Banyak faktor yang mempengaruhi kesehatan, baik kesehatan individu maupun kesehatan masyarakat. Faktor yang mempengaruhi derajat kesehatan adalah lingkungan, perilaku, pelayanan kesehatan, dan herediter. Ke empat faktor tersebut disamping berpengaruh langsung kepada kesehatan, juga saling berpengaruh satu sama lainnya. Status kesehatan akan tercapai secara optimal, bilamana ke empat faktor tersebut secara bersama-sama mempunyai kondisi yang optimal ${ }^{2,5}$.

Pada wanita hamil yang merokok atau terpapar asap rokok (perokok pasif), berisiko lebih besar mengalami keguguran atau melahirkan bayi dengan berat badan rendah dan mudah terinfeksi. BBLR akan berdampak, pada organ tubuh dan fungsinya kurang sempurnah,pertumbuhannya lambat,dan kecerdasan jadi terganggu. Sehingga penulis tertarik untuk membahas hubungan keterpaparan rokok terhadap BBLR ${ }^{2,5}$

\section{Tinjauan Tentang BBLR}

Bayi berat lahir rendah (BBLR) adalah bayi yang lahir dengan berat badan kurang dari 2.500 gram yang ditimbang pada saat lahir sampai dengan 24 jam pertama setelah lahir . Berat badan lahir normal (BBLN) adalah bayi yang lahir dengan berat badan 2.500 gram sampai 4.000 gram $^{1,5}$

ciri - ciri yang dapat dilihat pada BBLR yaitu:

1. Lebih kurus

2. Memiliki lemak tubuh yang lebih sedikit.

3. Memiliki ukurang kepala yang lebih besar dibanding dengan ukurang normal.

\section{Tinjauan Tentang Faktor risiko BBLR}

1. Faktor ibu hamil merokok baik perokok aktif maupun pasif, status gizi ibu hamil, jarak kehamilan, umur ibu hamil, paritas, frekuensi ANC (Ante Natal Care) dan penyakit atau komplikasi lain dalam kehamilan serta beberapa penyebab lain yaitu: 
a. Pendidikan

ibu yang memiliki pendidikan yang tinggi semakin mudah memahami cara menjaga kesehatan selama kehamilan. Begitu pula sebaliknya. Ibu yang memiliki pendidikan rendah menyebabkan kurangnya pemahaman akan kesehatan saat kehamilan ${ }^{2,5}$

b. Pekerjaan

Ibu yang memiliki pekerjaan berat dan melelahkan dapat mengganggu kondisi kesehatan dirinya dan kandungannya. Hal ini dapat menyebabkan kelelahan yang berlebihan sehingga menyebabkan terjadinya gangguan perkembangan janin

c. Umur

Umur reproduksi optimal pada wanita berada di antara 20 - 35 tahun. Karena pada umur tersebut, rahim sudah siap untuk menerima kehamilan . Sedangkan saat umur kurang dari 20 tahun, organ-organ reproduksi wanita belum dapat berfungsi dengan sempurna. Demikian pula dengan wanita yang berusia lebih dari 35 tahun. Organ reproduksi wanita mulai mengalami penurunan kesehatan yang disebabkan oleh proses degeneratif. Kedua hal ini merupakan faktor risiko terjadinya $\mathrm{BBLR}^{2,5}$

d. Status Gizi

Status gizi ibu pada masa kehamilan dapat mempengaruhi perkembangan janin dalam kandungan. Kekurangan gizi pada masa kehamilan dapat mengganggu pertumbuhan dan perkembangan janin yang dapat menyebabkan BBLR $^{1,5}$.

e. Paritas

Jumlah anak yang pernah dilahirkan oleh ibu berpengaruh pada pertumbuhan janin. Seorang ibu yang sering melakukan 17 persalinan memiliki kondisi rahim yang semakin melemah karena adanya jaringan parut di uterus yang disebabkan oleh kehamilan yang berulang-ulang. Hal ini dapat menyebabkan tidak adekuatnya aliran darah ke plasenta yang menyebabkan kurangnya nutrisi ke janin sehingga pertumbuhan janin terganggu ${ }^{1}$.

f. Riwayat BBLR sebelumnya

Interval kelahiran Jarak kelahiran anak dibawah dua tahun dapat mengakibatkan pertumbuhan janin yang kurang baik. Hal ini disebabkan oleh 
kondisi rahim yang masih lemah, dan kesehatan ibu yang belum pulih sepenuhya ${ }^{1,2}$.

g. Penyakit Komplikasi kehamilan seperti anemia sel berat, perdarahan antepartum, hipertensi, preeklampsia berat, eklampsia, infeksi selama kehamilan, dapat menyebabkan BBIR ${ }^{1,2}$

h. Tingkat sosial ekonomi Kejadian bayi berat lahir rendah sering terjadi pada ibu dengan tingkat sosial ekonomi rendah ${ }^{5,6}$

i. Sebab lain: ibu perokok, peminum alkohol, pecandu obat narkotik, atau menggunakan obat antimetabolik. ${ }^{1}$

2. faktor janin kelainan kromosom, , radiasi dan kehamilan ganda/kembar., infeksi janin kronik (inklusi sitomegali, rubella bawaan), disautonomia familial, dan gawat janin ${ }^{1,2}$

3. faktor plasenta

plasenta yang dapat menyebabkan BBLR yaitu berat plasenta berkurang atau berongga, infark, tumor,Faktor hidramnion, luas permukaan plasenta yang berkurang, plasenta previa, solutio plasenta, sindrom transfusi bayi kembar (sindrom parabiotik), dan ketuban pecah dini. ${ }^{1,2,4,5}$

4. faktor lingkungan

Lingkungan yang berpengaruh antara lain tempat tinggal yang berad di dataran tinggi, paparan radiasi, dan paparan zat beracun seperti yang terkandung dalam asap rokok.

a. Faktor lain yang dapat menjadi penyebab BBLR

adalah anemia selama kehamilan. Hemoglonin berperan penting untuk mengikat oksigen yang akan diedarkan ke seluruh organ tubuh untuk proses metabolisme dan pertumbuhan serta perkembangan organ-organ tubuh janin. Kadar hemoglobin yang rendah menyebabkan suplai oksigen dan nutrisi ke janin akan kurang sehingga dapat terjadi intra uterine growth retardation (IUGR). Apabila kondisi ini berlanjut tidak tertangani, maka akan terjadi BBLR. Penelitian ini bertujuan mengetahui seberapa besar efek dari pajanan asap rokok dan anemia terhadap BBLR ${ }^{1,5,6}$

b. Faktor lain terjadinya BBLR adalah faktor sosiodemografi, faktor genetik dan konstitusional, nutrisi, kesakitan ibu, terpapar toxic, faktor obstetrik dan perawatan prenatal. Rokok merupakan agent toxic selama kehamilan sebagai 
faktor penting dan independen resiko BBLR. Meskipun perokok pasif terpapar toxicnya lebih rendah daripada perokok aktif, namun efek samping sangat $\operatorname{mirip}^{5.6}$

\section{Tijauan tentang Keterpaparan Rokok Pada bu Hamil}

keterpaparan rokok dapat berpengaruh terhadap kehamilan yang sangat serius. Rokok dapat mengurangi aliran darah ke plasenta sehingga berisiko menimbulkan gangguan pertumbuhan janin. Rokok juga dapat meningkatkan risiko keguguran, berat badan bayi rendah, dan gangguan saluran pada nafas bayi.serta resiko infeksi akan meningkat, prematuritas, asfiksiparu janin pada preterm dapat meningkat dari keadaan normal $^{4,5}$

\section{Tijauan tentang Hubungan Antara Keterpaparan Rokok Dengan BBLR}

Keterpaparan asap rokok dapat menyebabkan faktor risiko berat plasenta ringan, atau ibu yang terpapar asap rokok berisiko 3,450 kali, lebih besar mengalami berat plasenta ringan, dibanding ibu yang tidak terpapar asap rokok.serta terpapar asap rokok juga dapat mengurangi aliran darah ke plasenta sehingga berisiko menimbulkan gangguan pertumbuhan janin. Dan meningkatkan risiko keguguran, berat badan bayi rendah, dan gangguan saluran pada nafas bayi.

Sehingga dapat disimpulkan bahwa BBLR sangat dipengaruhi oleh banyak faktor diantaranya adalah ibu hamil yang terpapar asap rokok dan anemia pada masa kehamilan. beresiko tuju kali mengalami BBLR dan ibu hamil yang anemia juga beresiko enam kali melahirkan bayi BBLR. Serta Ada banyak faktor yang berkontribusi terhadap BBLR, baik ibu maupun dari ibu,janin,lingkungan dan dll.. Berat badan saat lahir secara langsung dipengaruhi oleh tingkat umum status kesehatan ibu. Lingkungan ibu adalah penentu paling penting dari berat lahir dan

faktor-faktor yang mencegah sirkulasi normal di plasenta yang menyebabkan gizi buruk dan pasokan oksigen ke janin kurang, sehingga membatasi pertumbuhan janin. Faktor risiko ibu secara biologis dan sosial sebagian besar saling terkait. Faktorfaktor yang bervariasi dari satu daerah ke daerah lain, tergantung pada faktor-faktor geografis, sosial ekonomi dan Budaya.dan dari hasil penelitian dari dua jurnal yang berbeda ,saya menemukan hasil yang hampir sama mulai dari pembahasan dan faktorfaktor penyebeb serta akibat yang akan ditimbulkan jika terpapar asap rokok terhadap ibu dan BBLR.,diharapankan Dalam menanggulangi risiko kejadian BBLR sebaiknya 
dengan mempertimbangkan usia pada saat ingin merencanakan kehamilan yaitu pada usia reproduktif (21-35 tahun), rutin melakukan kunjungan ANC minimal 4 kali selama hamil, anggota keluarga di rumah sebaiknya tidak merokok didalam rumah maupun disamping ibu, dan sebaiknya ibu tidak terlalu sering untuk melakukan kegiatan yang mudah membuat ibu lelah ${ }^{1,2,3,4,5}$ 


\section{DAFTAR PUSTAKA}

1. Lestari,safaringga,Alya D. 2013. Faktor-Faktor yang Berhubungan dengan BBLR di RSIA Banda Aceh. Banda Aceh: Sekolah Tinggi Kesehatan U'Budiyah

2. Ridwan, 2014. Analisis Risiko Asap Rokok Dan Variasi Gen CYP2A6 Terhadap Berat Plasenta Dan Dampaknya Pada Kejadian Bayi Berat Lahir Rendah. Universitas Hasanuddin.

3. Prawirohardjo, Manuaba (2014). Buku Ajar Asuhan Kebidanan. Jakarta : EGC.

4. Fahira Nur, Adhar Arifuddin, Hermiyanti (2018). Faktor Risiko Plasenta Ringan Pada Ibu Bersalin Di RSU Anutapura Palu. Jurnal Kesehatan Tadulako Vol. 4 No. 1,Januari20181-56

http://jurnal.untad.ac.id/jurnal/index.php/HealthyTadulako/article/view/10222 diakses pada tanggal 26 September 2019.

5. Mahdalena, M., P Ningsih, E. S., \& Noor, S. (2016). PENGARUH ROKOK TERHADAP BERAT BADAN BAYI BARU LAHIR DI RSUDBANJARBARU. Jurnal Skala Kesehatan, 5(2).

.http://www.ejurnalskalakesehatan-poltekkesbjm.com/index.php/JSK/article/view/23 diakses pada tanggal 12 april 2016

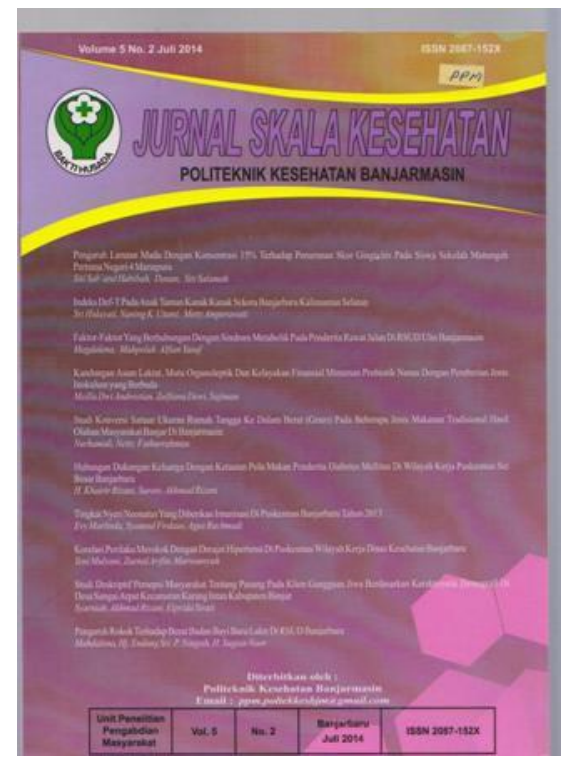

